\title{
SISTEM INFORMASI MANAJEMEN
}

(resume materi sistem informasi manajemen)

\author{
Salma Sakinah \\ 1611050027 \\ System Informasi
}

Salma.1611050027@mail.darmajaya.ac.id

\begin{abstract}
Sistem informasi manajemen adalah sistem perencanaan bagian dari pengendalian internal suatu bisnis yang meliputi pemanfaatan manusia, dokumen, teknologi, dan prosedur oleh akuntansi manajemen untuk memecahkan masalah bisnis seperti biaya produk, layanan atau suatu strategi bisnis. Disni ada tugas seorang manajer yaitu mengelola sumber daya agar dapat digunakan secara efektif untuk mengontrol biaya, data dan mengelola sumber daya. Adapun tugas seorang direktur yaitu mengetahui sistem yang ada di manajer dari direktur dan memberi kebijakan dari direktur, seperti memberi persetujuan izin dari direktur.

Data dan informasi : Data yaitu produk dan jasa.

Ada 3 dari data yaitu : - informasi, - data, informatika

- Informasi yaitu interprestasi dari data yang dari mentah dijadikan informasi, atau sesuatu yang bisa disajikan ada objek

- Informatika biasanya akan disebut dengan penerapan dan studi informasi yang hasilnya nanti akan masuk kedalam informasi atau objek yang sudah jadi seperti buku.

Bentuk sistem informasi yaitu:
\end{abstract}

1. Sistem informasi manajemen

2. Sistem informasi eksekutif

3. Sistem informasi perkantoran

4. Sistem informasi pendukung keputusan

5. Sistem informasi proses transaksi

6. Sistem informasi pendukung pakar

Adapun perbedaan sistem informasi dan teknologi informasi

Sistem informasi adalah kombinasi antara sumberkerja yang dikumpulkan untuk mencapai tujuan dalam sebuah organisasi. Sedangkan teknologi informasi yaitu mencakup perangkat keras, perangkat lunak untuk melaksanakan sejumlah tugas pemrosesan data seperti mentransmisikan, menyimpan data, memanipulasi, menampilkan data sehingga dapat diteraokan dalam sebuah organisasi.

Kata kunci : system informasi manajemen 
